\title{
Implications of Blockchain Technology in Supply Chain Management
}

\author{
Rekha Goyat $^{1}$, Gulshan Kumar ${ }^{2}$, Mritunjay Kumar Rai ${ }^{3}$, Rahul Saha ${ }^{2}$ \\ ${ }^{1,3}$ School of Electronics and Electrical Engineering, Lovely Professional University, \\ Phagwara, Punjab, India \\ ${ }^{2 *}$ School of Computer Science and Engineering, Lovely Professional University, \\ Phagwara, Punjab, India \\ gulshan3971@gmail.com
}

\begin{abstract}
Due to rapid developments in technology, the supply chain becomes a bright area of interest among up-and-coming careers in various industries. People with careers in this field oversee such activities as product development, production, information systems, transportation, and day-to-day logistics. But, the rapidly evolving environments of an easy and comfortable life, the demand for product visibility and end-to-end traceability have grown. The existing supply chain is inefficient, unadaptable, intractable and costly as compared to innovative and advanced technology. Blockchain is the emerging and revolutionary technology that impacts the supply chain networks significantly. Therefore, in this paper, the implication of blockchain technology in the supply chain is presented.
\end{abstract}

Keywords: Supply chain management, Blockchain, Distributed ledger, Transactions, Trust.

\section{Introduction}

The rapid advancement in digital communication has allowed for quicker, easier connectivity between businesses and customers. With the development in technology, the customers' expectations and their needs have increased with regards to delivery on time, transparency, good quality of products and response times. Supply chain management (SCM) is defined as the management of the flow of goods and services that transform raw materials into final products. In other words, to control the flow of any products from raw state to final customers in the most streamlined and cost-effective way represents the SCM process. It protects the distribution of all goods from manufacturing to end product. The production, shipment, and distribution of any product are controlled in a centralized manner. Also, SCM reduces the excess cost of products and delivers to the customer in the 
fastest way. Every product reaches at markets with a lot of efforts of different groups. The basic process of SCM is depicted in Figure 1.

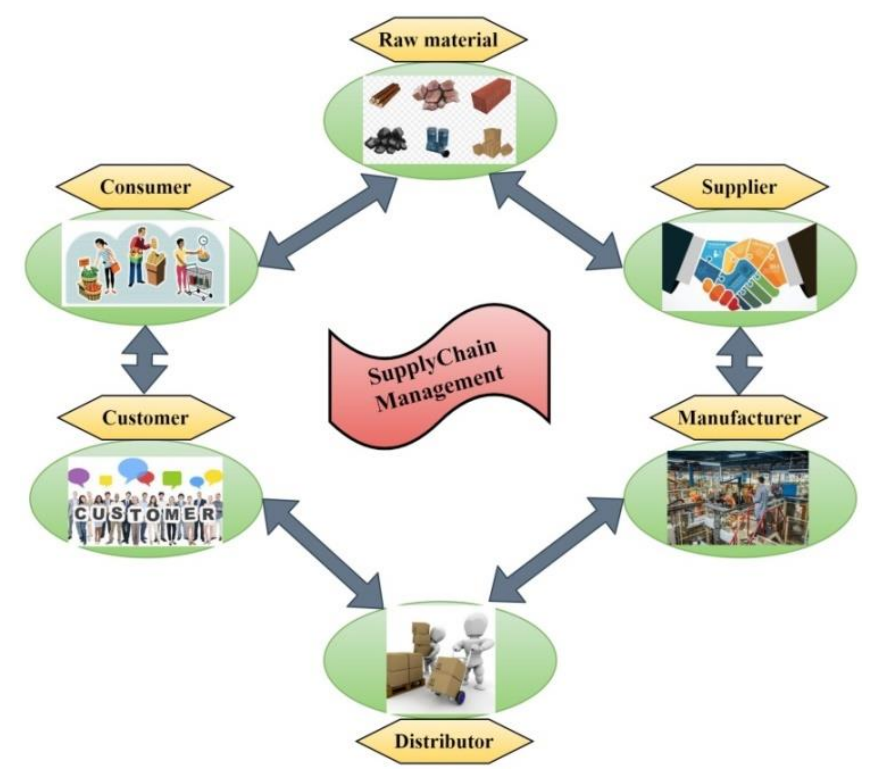

Fig. 1: A basic process of Supply chain management

\subsection{Challenges and risks in SCM}

The modernization of the supply chain has a great experience and it is an important factor for various organizations which affects competitiveness. The supply chain has different risks inherent that are connected to its nature4. (Chain and Sscm, 2006). SCM has various challenges fed by various internal and external factors. Globalization and global connectivity of the supply chain increase the complexity and risks for SCM. Others challenges are inherent to the never-ending struggle for better efficiency and to reduce the overall operating cost of the products(Chain et al., 2010). In manufacturing, to reduce lifecycles of products, outsourcing, Just in Time inventory, proper utilization of machinery and consolidation of the supplier are factors of any business models that carried significant improvement and important challenges and risks to supply management (Eyers, 2017). Various risks and challenges of SCM are depicted in Figure 2 and discussed as following: 


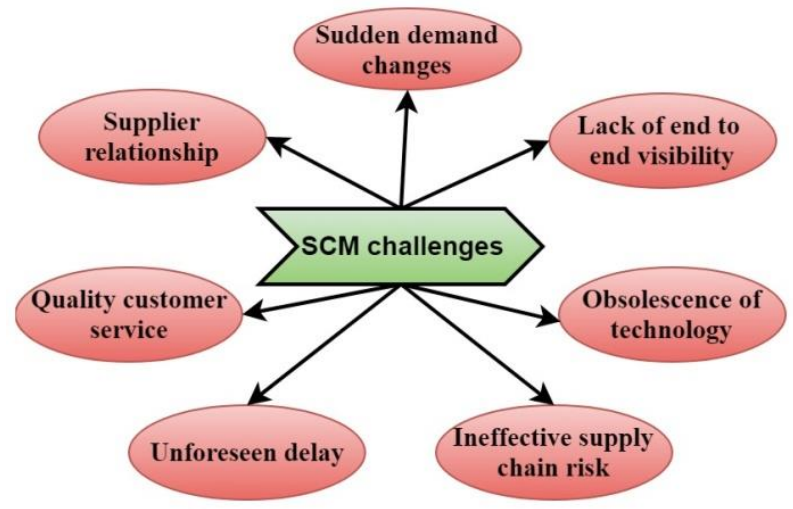

Fig. 2: Challenges and risks in SCM

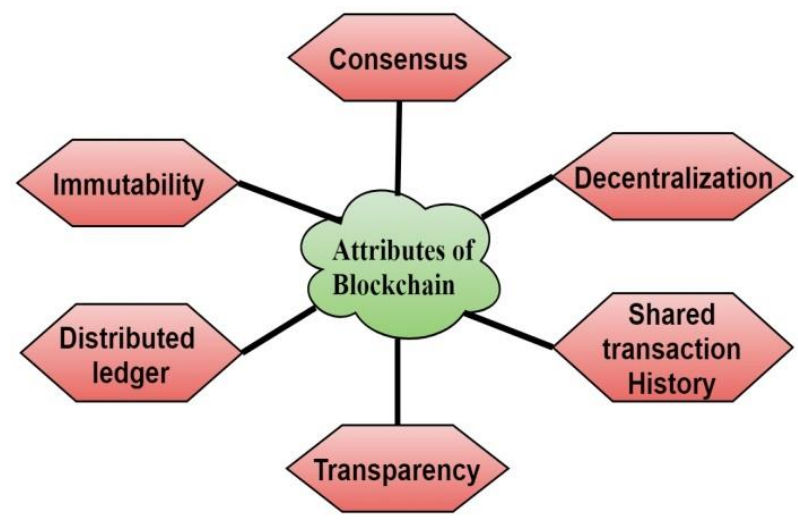

Fig. 3: Blockchain attributes

1. Sudden demand changes: Due to advancement in technology the demand for markets changes frequently every day and it is quite difficult to adapt the variations in the markets. Rapidly fluctuating in markets requires businesses to react quickly to sudden changes with good efficiency.

2. Lack of end to end visibility: Most of the organizations are struggling to have proper details about their supply chain externally and internally. This exposes the risk of fraud, mishandling, and code of conduct violations, etc. (Lourenço and Ravetti, 2018).

3. Obsolescence of technology: Significant and appropriate investments are required for growth of SCM and it is a major challenge for most businesses (Szegedi and Kerekes, 2012).

4. Ineffective supply chain risk: To control, monitor and predict the supply chain risk, an effective supply chain management programs are an important key factor to react on time.

5. Unforeseen delay: To track the progress of products and materials in the 
supply chain may be easy, but the delivery of particular products on time may not always be $100 \%$ on time due to time differences and different shipping frames ( $\mathrm{Ji}, 2007)$.

6. Quality customer services: SCM works in a centralized manner to fulfill the requirements of the customers. It represents the supply of products at the right time with the right quantity and good quality with affordable amount of money. It is not a simple process because customers have different preferences with time (Henrie and Hedgepeth, 2006).

7. Supplier relationship: To create a mutual association with various suppliers in marketing is a challenging issue in SCM.

Advancement in emerging technology has attracted attention from centralized systems to the decentralized one (Nakamoto, 2008). Blockchain technology provides a significant contribution in the field of trust, comfort, robust, traceability and transparency with distributed ledger13. ～(Efanov and Roschin, 2018; Filippi and Hassan, 2016). Blockchain represents the peer to peer decentralized network with a distributed immutable ledger which has all transactions accomplished by participants (Lewis, 2016). Blockchain is quite simply a single version of the truth that can be viewed and shared by a number of users (Devine, 2017). Distributed nature of blockchain eliminates intermediaries in the supply chain and has the proficiency to reinvent it. It provides control and management to every stakeholder as per their needs be it terminal operators, inland carriers, ocean carriers, financial authorities or service providers (Iansiti and Lakhani, 2017).

\subsection{Attributes of the blockchain technology}

The blockchain technology is essence database which collects, control and monitors the information. The information is stored in blocks and each block has a finite set of records and transactions maintain a chain by connecting all bocks in a predefined order (Meunier, 2018). The blockchain holds the present records of a transaction with its complete history. The incorporation of blockchain technology in supply chain offers a number of benefits as compared to the classical supply chain. Decentralization of data is the most important feature of blockchain technology which leads provides more transparency to transactions. Every participant holds the actual dataset but not able to fraud or temper the dataset (Appelbaum and Smith, 2018). A small change in the dataset is publicly shared with every participant. The inability to modify or tamper with transactions in blockchain enables to join trusty participants and offer immutability to the dataset. Various attributes of blockchain technology are shown in Figure 3.

\subsection{Blockchain in SCM}

Development in shopping options through eCommerce and mCommerce has made 
supply chain management a crucial issue of concern for various organization or businesses. For large manufacturing industries or companies, it is the most critical problem to deliver their products to supply chain partners (Wong and Ngai, 2019). With an increasing emphasis on technological advancements, as well as the changes in customer expectations, the need for integrated supply management has become increasingly important (Moretto et al., 2019). Various limitations that are faced by different supply chain actors and the impact of Blockchain on supply are summarized in Table 1.

Table 1. Various limitations faced by different supply chain actors and the impact of blockchain

\begin{tabular}{|c|c|c|}
\hline $\begin{array}{l}\text { Supply chain } \\
\text { roles }\end{array}$ & $\begin{array}{l}\text { Limitations of current } \\
\text { blockchain }\end{array}$ & Impact of blockchain on SCM \\
\hline Raw material & $\begin{array}{l}\text { Producer of raw materials } \\
\text { should have the capability to } \\
\text { prove the origin and quality } \\
\text { globally with transparency }\end{array}$ & $\begin{array}{l}\text { Using blockchain, materials can be } \\
\text { tracked from the production of the } \\
\text { raw item and trust can be } \\
\text { maintained from start point to end } \\
\text { consumer point. }\end{array}$ \\
\hline Supplier & $\begin{array}{l}\text { Suppliers are responsible for } \\
\text { agreements or contracts between } \\
\text { a company and its supplier. } \\
\text { Lack of transparency influence } \\
\text { the supplier's efficiency. }\end{array}$ & $\begin{array}{l}\text { Trust is maintained using } \\
\text { blockchain and it also offers } \\
\text { transparency between documents or } \\
\text { agreements. }\end{array}$ \\
\hline Manufacturer & $\begin{array}{l}\text { Manufacturers have restricted } \\
\text { capability to monitor the } \\
\text { products from source to } \\
\text { destination. Also has limited } \\
\text { capability to measure the quality } \\
\text { of raw products. }\end{array}$ & $\begin{array}{l}\text { The distributed consensus of } \\
\text { blockchain technology added value } \\
\text { from a raw material producer to its } \\
\text { suppliers. }\end{array}$ \\
\hline Distributor & $\begin{array}{l}\text { Certification and trust issues are } \\
\text { having limited capability and } \\
\text { custom tracking systems are } \\
\text { with least collaboration. }\end{array}$ & $\begin{array}{l}\text { Proof-of-identification, smart } \\
\text { contracts, and proof-of-locations } \\
\text { provide the ability of certification } \\
\text { in the distributed ledger. }\end{array}$ \\
\hline wholesaler & $\begin{array}{l}\text { Traditional supply chain } \\
\text { management has a lack of trust } \\
\text { and certification of materials. }\end{array}$ & $\begin{array}{l}\text { With blockchain, the wholesale is } \\
\text { able to check the origin of the } \\
\text { products, their certification, the } \\
\text { transformation of goods and } \\
\text { transportation conditions. }\end{array}$ \\
\hline
\end{tabular}




\begin{tabular}{|c|c|c|}
\hline $\begin{array}{c}\text { Retailer/Custo } \\
\text { mers }\end{array}$ & $\begin{array}{c}\text { Traditional supply chain } \\
\text { management has a lack of trust } \\
\text { and certification of materials. }\end{array}$ & $\begin{array}{c}\text { The retailer is able to track the } \\
\text { individual products between the } \\
\text { wholesaler and end-user. Ability to } \\
\text { return of malfunctioning products } \\
\text { effectively }\end{array}$ \\
\hline Consumers & $\begin{array}{c}\text { The consumers are not able to } \\
\text { track the origin of products, } \\
\text { their quality, and certification of } \\
\text { products with the specified } \\
\text { standard. }\end{array}$ & $\begin{array}{c}\text { Blockchain provides full } \\
\text { transparency to consumers from the } \\
\text { raw stage to the final stage of the } \\
\text { products with product origin and } \\
\text { their certification. }\end{array}$ \\
\hline
\end{tabular}

Within the supply chain management, a supply chain is the connected network of individuals, organizations, resources, activities, and technologies involved in the manufacture and sale of a product or service (Cole et al., 2019). With blockchain, users across the supply chain get access to an automated digital system that marks all changes and records the exchange of hands without any human intervention (Kouhizadeh et al., 2018). Every transaction or entry recorded in blockchain is in many ways more efficient and honest. The system ensures that no piece of inventory exists in the same place twice while it moves ahead in the chain (Partida, 2018). This way, it gives a unified view and real-time status updates with full traceability of actions. This drastically cuts down the time taken to trade internationally and removes all physical procedures that ever existed (ElMessiry and ElMessiry, 2018; Partida, 2018).

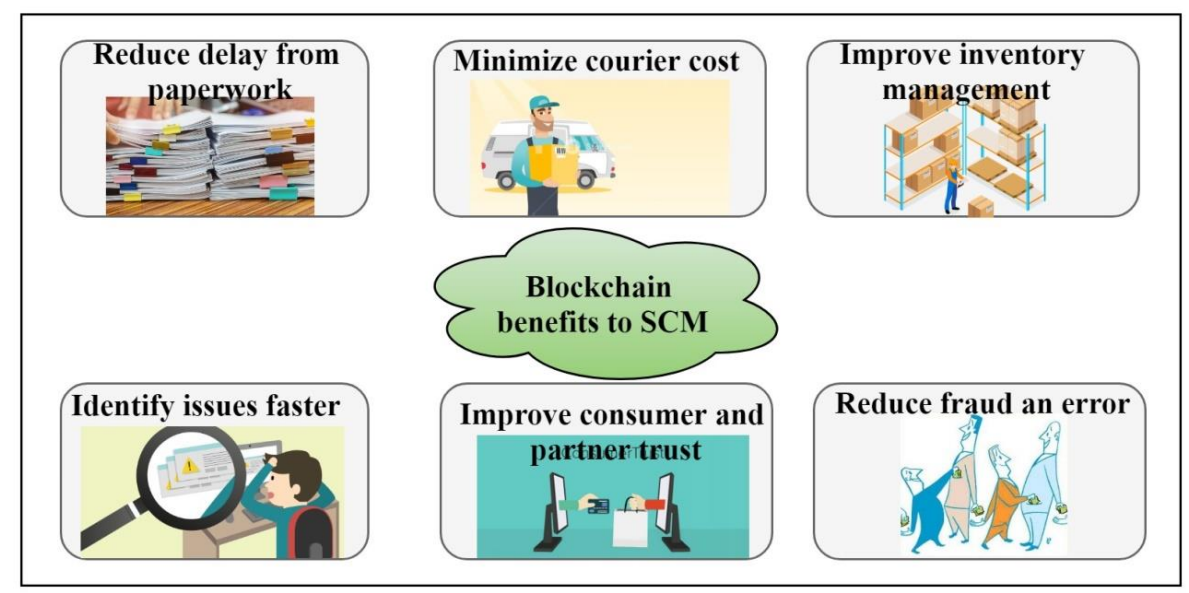

Fig. 4: Advantages of blockchain to SCM

Various benefits of blockchain technology are highlighted in SCM as shown in figure 4. Delay in work supply due to paperwork can be reduced via blockchainbased SCM. In this method, all the history of transactions and data is stored in a 
distributed manner and any authorized party can utilize that information. Incorporation of blockchain in SCM improves the trust relationship among consumers, customers, manufacturers, and suppliers. As a part of the blockchain ecosystem, sellers and buyers alike are always who they say they are and products are always the right ones. What's more, because prices cannot be modified, the whole process of invoices will be rendered obsolete in the future. If a purchase order is represented as a block in the blockchain, it invariably becomes an immutable digital entity. Impact of various attributes on supply chain management is discussed in Table 2.

\section{Proposed Blockchain-based SCM}

Blockchain technology has the potential to renovate the way through which organizations do work in the supply chain. The integrated process enables all participants to access the information or data at any point and any time in the network. Any participants that are willing to access the supply chain need to be registered in the blockchain technology. Once they have registered, they can participate in initializing, validating and tracking of goods as per their requirements. In Figure 5, the working principle of incorporation SCM with blockchain is depicted. Firstly, the request for the new transaction from the network is generated and appended to block after verification. The more detail about buyers and suppliers are recorded on each block at each stage. Each block comprises different information such as certification, production date, batch number, the weight of goods, temperature, etc. All the information is recorded in decentralized ledger acts as single unified source of the dataset such as raw material, manufacturing, maintenance process, and supply, etc. (Angrish et al., 2018).

Table 2: Blockchain attributes that impact supply chain management

\begin{tabular}{|l|l|}
\hline \multicolumn{1}{|c|}{$\begin{array}{c}\text { Relation and impact of blockchain on supply chain } \\
\text { management }\end{array}$} \\
\hline Consensus & $\begin{array}{l}\text { Blockchain consensus provides the ability to stakeholder to } \\
\text { track the whole process of supply chain and offers trust to } \\
\text { SCM. As the all features such as certification, quality, } \\
\text { quantity and other details of products are recorded in } \\
\text { consensus which adds value to its final products. The quality } \\
\text { of raw materials are validated, certification of manufacturers } \\
\text { is checked which gives more transparency and added value to } \\
\text { the final product. }\end{array}$ \\
\hline
\end{tabular}




\begin{tabular}{|c|c|}
\hline $\begin{array}{l}\text { Distributed ledger } \\
\text { / Decentralization }\end{array}$ & $\begin{array}{l}\text { Blockchain works in a decentralized manner that means } \\
\text { information is not handled by a single node. All the } \\
\text { information regarding the products from its raw stage to the } \\
\text { final stage is stored in a distributed way and it is publically } \\
\text { available based on some agreements. It avoids the risks of } \\
\text { data loss or one-point failure. Additionally, data alteration and } \\
\text { manipulation is difficult in distributed ledger. }\end{array}$ \\
\hline $\begin{array}{c}\text { Privacy/ } \\
\text { immutability }\end{array}$ & $\begin{array}{l}\text { Blockchain is distributed in nature having public ledger and } \\
\text { designed in such a way to enable access control to who is able } \\
\text { to have access on the ledger. Before accessing the data of } \\
\text { ledger, the authentication of each controller is checked using } \\
\text { some decision process. It provides privacy to information that } \\
\text { is not visible to all (only legitimate parties allowed) and it } \\
\text { verifies the essential information during authentication. The } \\
\text { distributed ledger is immutable in nature and manipulation or } \\
\text { tampering is not possible. }\end{array}$ \\
\hline $\begin{array}{l}\text { Transparency } \\
\text { / Scalability }\end{array}$ & $\begin{array}{l}\text { With blockchain technology, the entire stakeholder } \\
\text { participates in a universal system of the supply chain. The } \\
\text { nature of blockchain is peer to peer which is designed in a } \\
\text { robust and scalable manner for eliminating a single point of } \\
\text { interaction. The distributed ledger is shared by stakeholder to } \\
\text { improve transparency and scalability. }\end{array}$ \\
\hline $\begin{array}{c}\text { Shared transaction } \\
\text { history }\end{array}$ & $\begin{array}{l}\text { Each transaction is included into blocks and each block } \\
\text { contains a hash function of previous blocks into the } \\
\text { blockchain. The hash function of block maintains the integrity } \\
\text { of the recorded information. All the past transactions are } \\
\text { recorded into blocks and are shared among different legitimate } \\
\text { parties. }\end{array}$ \\
\hline
\end{tabular}




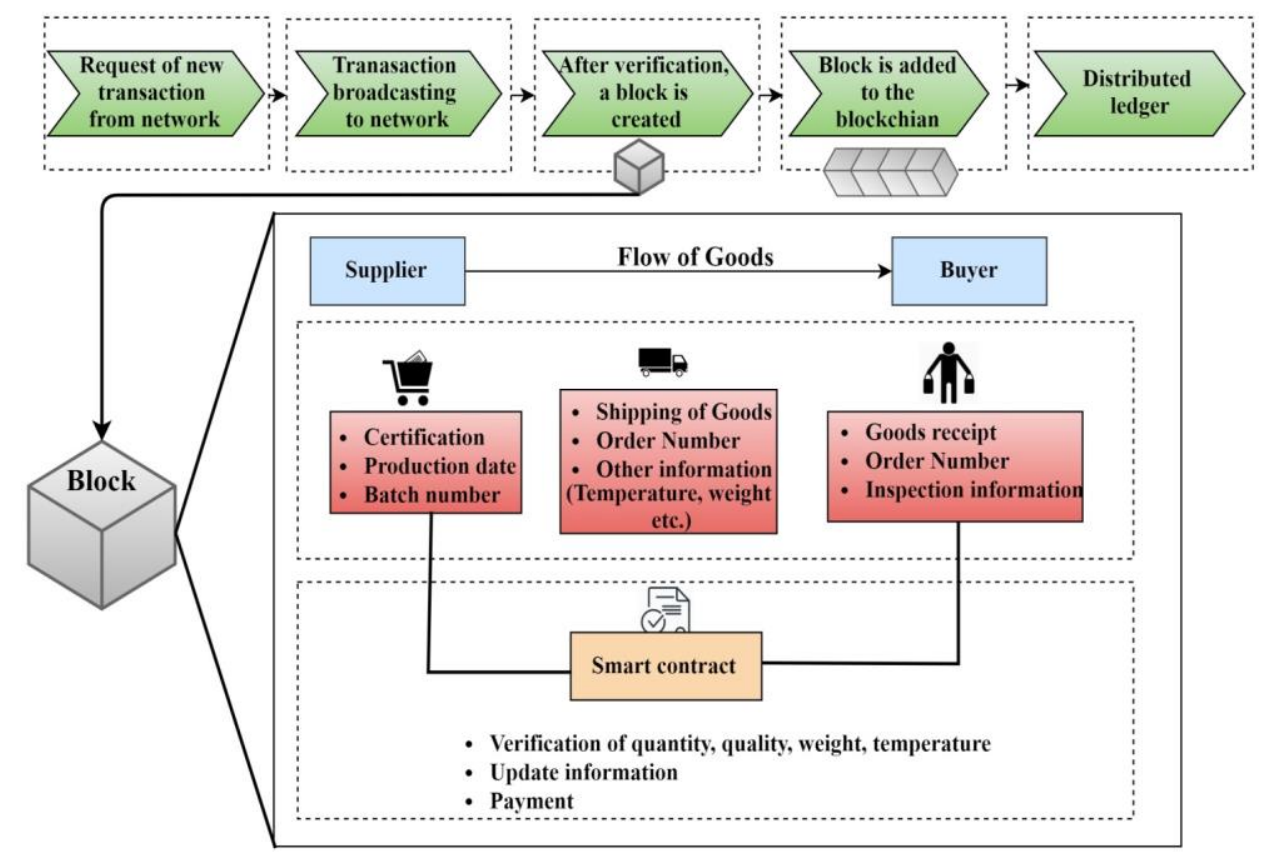

Fig. 5: Blockchain-based SCM
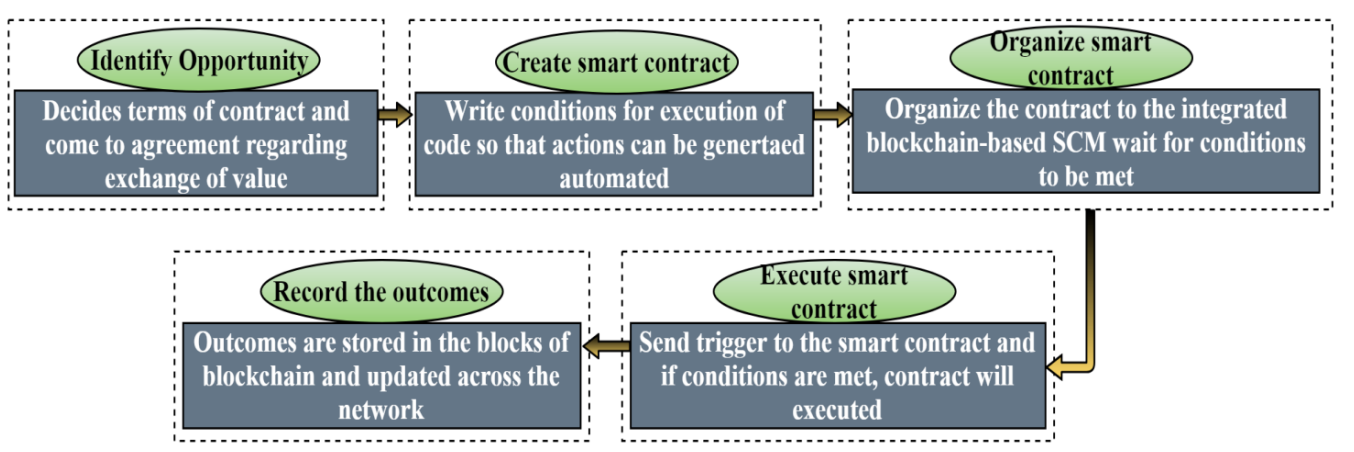

Fig. 6: Smart-contract process in blockchain-based SCM

Initially, to create smart contract each party must identify an opportunity on which they collaborate and must agree about all the outcomes for each party as shown in Figure 6. It is considered in the proposed scheme that each party or stakeholder who are willing to access the blockchain data, require to be registered with integrated Blockchain with supply chain network. Once all the parties are registered, the account assignment process is applied by them for generating a combination of the public-private key. The public-private keys are utilized by each party for creating or verifying each transaction.

\section{Conclusion}

Supply chain management is an essential and integral part of various businesses 
which is responsible for the continued growth of company and customers satisfaction. In this paper, an integrated approach using blockchain in the supply chain is proposed to resolve the various challenges. The proposed solution offers a real-time distributed ledger of all transactions and movements of all participants and products in their network of the supply chain. The supply chain with blockchain has a significant future because it delivers an efficient, transparent, decentralized, immutable and collaborative network to all businesses. Theoretically, it is identified that blockchain technology enables all organizations to develop a more flexible and responsible supply chain and address new external and internal challenges.

\section{References}

A. Angrish, B. Craver, M. Hasan, and B. Starly, "A Case Study for Blockchain in Manufacturing: 'fabric': A Prototype for Peer-to-Peer Network of Manufacturing Nodes," in Procedia Manufacturing, 2018, vol. 26, pp. 1180-1192.

A. Lewis, "Blockchain Technology Explained," Blockchain Technologies, 2015. [Online]. Available: http://www.blockchaintechnologies.com/blockchain-definition.

A. Moretto, L. Grassi, F. Caniato, M. Giorgino, and S. Ronchi, "Supply chain finance: From traditional to supply chain credit rating," Journal of Purchasing and Supply Management, vol. 25, no. 2, pp. 197-217, 2019.

B. Partida, “Blockchain's great potential: Blockchain's potential is immense, but most organizations have not yet made the investment.," Supply Chain Management Review, vol. 22, no. 1, pp. 51-53, 2018.

Council of Supply Chain Management Professionals, "CSCMP Supply Chain Management definitions," Http://Cscmp.Org/, 2015. [Online].

Available:https://cscmp.org/imis0/CSCMP/Educate/SCM_Definitions_and_Glossar y_of_Terms/CSCMP/Educate/SCM_Definitions_and_Glossary_of_Terms.aspx?hke $\mathrm{y}=60879588-\mathrm{f} 65 \mathrm{f}-4 \mathrm{ab} 5-8 \mathrm{c} 4 \mathrm{~b}-6878815 \mathrm{ef} 921$.

Council of Supply Chain Management Professionals, "Supply chain management: Terms and Glossary," Healthcare informatics : the business magazine for information and communication systems, vol. 17, no. 2, pp. 58-60, 2013.

D. Appelbaum and S. S. Smith, "Blockchain Basics and Hands-on Guidance," The CPA Journal, 2018. [Online]. Available:

https://www.cpajournal.com/2018/06/19/blockchain-basics-and-hands-on-guidance/

D. Efanov and P. Roschin, "The all-pervasiveness of the blockchain technology," in Procedia Computer Science, 2018, vol. 123, pp. 116-121. 
D. R. Eyers, "Supply chain risk management for sustainable additive manufacturing," in Smart Innovation, Systems, and Technologies, 2017, vol. 68, pp. 280-288.

D. T. W. Wong and E. W. T. Ngai, "Critical review of supply chain innovation research (1999-2016),’ Industrial Marketing Management. 2019.

G. Ji, M. Center for Supply Chain, and Logistics, "Design Principles and Evaluation for Closed-loop Supply Chains," in Icoscm 2007 - International Conference on Operations and Supply Chain Management in China, vol. 1, 2007

H. R. Lourenço and M. G. Ravetti, "Supply chain management," in Handbook of Heuristics, vol. 2-2, 2018, pp. 1241-1258.

K. Szegedi and K. Kerekes, "Challenges of Responsible Supply Chain Management," Theory Methodology Practice (TMP), vol. 8, no. 2, pp. 68-75, 2012.

M. ElMessiry and A. ElMessiry, "Blockchain framework for textile supply chain management: Improving transparency, traceability, and quality," in Lecture Notes in Computer Science (including subseries Lecture Notes in Artificial Intelligence and Lecture Notes in Bioinformatics), 2018, vol. 10974 LNCS, pp. 213-227.

M. Henrie and O. Hedgepeth, "Project management supply-chain challenges," in Proceedings of 20th IPMA World Congress on Project Management, Vols 1 and 2, 2006, pp. 982-985.

Marco Iansiti and Karim R. Lakhani, "The Truth About Blockchain," Harvard Business Review, vol. 95, no. January-February, pp. 118-127, 2017

M. Kouhizadeh, S. Saberi, J. Sarkis, and R. Island, "BLOCKCHAIN TECHNOLOGY AND SUSTAINABLE SUPPLY CHAINS.," Proceedings for the Northeast Region Decision Sciences Institute (NEDSI), p. 43, 2018.

P. Council of Supply Chain Management, "Supply chain management: Terms and Glossary," Healthcare informatics: the business magazine for information and communication systems, vol. 17, no. 2, p. 162, 2018.

P. De Filippi and S. Hassan, "Blockchain Technology as a Regulatory Technology," First Monday, vol. 21, no. 12, 2016.

.R. Cole, M. Stevenson, and J. Aitken, "Blockchain technology: implications for operations and supply chain management," Supply Chain Management, vol. 24, no. 4, pp. 469-483, 2019.

S. Chain and M. Sscm, "Risk Management in Sustainable Lessons Learnt from the Case of," Corporate Social Responsibility and Environmental Management, vol. 10, no. September 2005, pp. 1-10, 2006. 
Supply Chain Council, "Supply Chain Operations Reference Model," Supply Chain Operations Management, pp. 1-976, 2012.

S. Chain et al., "Supply Chain Risk Management in six steps," Supply Management, pp. 3-7, 2010.

S. Mansfield-Devine, "Beyond Bitcoin: using blockchain technology to provide assurance in the commercial world," Computer Fraud and Security, vol. 2017, no. 5, pp. 14-18, 2017

S. Meunier, "Blockchain 101: What is Blockchain and How Does This Revolutionary Technology Work?," in Transforming Climate Finance and Green Investment with Blockchains, 2018, pp. 23-34.

S. Nakamoto, "Bitcoin: A Peer-to-Peer Electronic Cash System," Consulted, pp. 19, 2008 . 